\title{
STOCK AND STOCK EXCHANGE AS A PART OF FINANCIAL INSTITUTIONS IN DEVELOPED COUNTRIES
}

\author{
Vesna Petrović, ${ }^{1}$ Nataša Simić ${ }^{2}$, Dušan Aničić ${ }^{3}$ \\ ${ }^{1,2}$ Faculty of entreneurship and real estate management, Union University-Nikola Tesla, Belgrade \\ ${ }^{3}$ DSN Konsalting, Belgrade, Serbia \\ anicic.dusan@yahoo.com
}

\section{Professional Paper doi:10.5937/jouproman6-15638}

\begin{abstract}
The authors have tried to present the term, meaning and importance of stocks and stock exchange as a part of the financial system of developed countries. By observing the financial system growth, especially in financial institutions, it can be noticed that there are changes in relative positions of various types of financial agents in developed market industries. What determines financial markets, and by that the stocks and stock exchange is the permanent movement of financial instruments and neglecting the national market boundaries.
\end{abstract}

Key words: capital market, business, market, index, stock, shares

\section{INTRODUCTION}

A fast financial market development in developed countries, first of all the USA, meant the development of the contemporary financial institution system development which was adjusted to the needs of investors as well as to all of the other asset users. The matter of this work also includes the capital market and its structure analysis, just as the stock structure and stock industry as a part of the aforementioned market. The aim is to show that the financial system as a part of the financial management is one of the key parts of the overall country's economy system. One country's financial system development can be monitored through the development rate of its financial institutions as the most important part of the system. As a part of the industrial system, the financial system comprises of multiple elements which enable uninterrupted flow of financial assets within one social-economic community (Aničić et all., 2017, p 36-44). It manages a great number of functions in industry: savings function, well-being function, liquidity function, credit function, paying function, protection from the risks, macroeconomics function, assets transfer through time and space function, providing the information, money making function. Financial system has multiple characteristics, most important being: dynamic, openness, complexity, hierarchy. ${ }^{9}$

\section{STOCKS AND STOCK INDUSTRY}

Stocks can be defined as market industries where standardized market goods are being traded at a determined place, at a determined time and by determined market rules. Stock exchange is the basic indicator of stability and prosperity of one country. Stock exchange is a defined set of rules to be obeyed by all the participants at the organized stock exchange. Stock exchange is institutionally organized space with specified rules of behaviour and business of every participant trading with securities of the capital market, i.e. effects. Hence, security finance is highly organized specialized capital institution, nonprofit institution owned by a country or a trading participant.

\footnotetext{
${ }^{9}$ Ristanović R, „Financial management“, Business High school, Belgrade, notebook, p.13
} 
Through the stock history, three stock concepts or systems have developed:

- Anglo American concept. This is a concept that represents stock exchange foundation and the basis of which is the legal form. According to this system, if the founders fulfill the requirements determined by law, the state cannot prevent them from founding it. In this case, the stock is a privatelylegal organization which has the features of a legal entity and which is founded on the basis of trade and civil law. The stock members are the only subjects capable of trading on the stock exchange, and those are real-estate agencies and banks specialized for trading in securities.

- Medieval concept which is based on German, Austrian, Hungarian, Polish and even FRY law, where the basis of the concept is that the stock is based on the previous completion of all legal regulations. Upon completion of checking the fulfillment of all the conditions, the securities board, as the state authority, makes the decision about the stock exchange operation approval. Only members can trade at this kind of stock exchange.

- French concept. This is a concept where stock exchange is a subject with no legal features. Only the stock exchange controlling organizations have the features of legal entities. This concept is also known as the state decision system, since the stock exchange alone is founded by decision of the state. It is adopted in French and Italian law. ${ }^{10}$

In case we observe different kinds of stock exchange instruments, stocks can be

\footnotetext{
${ }^{10}$ Ristanović V, „Financial management", Business High school Belgrade.
}

divided into commodity and financial exchange. Financial stock exchange can be further divided into universal and specified. Universal stock exchanges are the ones where securities are traded and which represent financial instruments on the capital market (owner's and long-term securities), but there is also the possibility of trading short-term securities, money, financial derivations (futures, options) and gold. Unlike those stock exchanges, only certain exchange instruments can be traded in specialized stock exchange. Those can be the effect stock exchange (where only securities are traded), foreign currency stock exchange, gold exchange, precious metal stock exchange etc.

The logical answer to the question of what the key function of stock exchange is, is that it provides a continuous securities market, the price of which will not drastically change from the one they were previously sold by. This market continuity is considered necessary since it enables securities liquidity without which it would be impossible to make investors invest in them. Stock exchanges enable transparency and reviewing the price of various securities, as well as the access to financial reports of the companies which issue them (Aničić et. all, 2017, p 45-54), to the existing and prospective investors in order to be able to estimate the risk and rentability of their investments and direct them in accordance with their preferences to the risk and rentability. ${ }^{11}$

One of the main reasons to create the stock exchange institution is protection of market risks, hence the stock exchange trading organization is devoted to that. This organization works by the concentric circle pattern, its center being the stock exchange itself along with its departments.

\footnotetext{
${ }^{11}$ Krasulja D; Ivanišević M, „Term of stock and stock exchange“, Belgrade, 1998.
} 
There is a circle of certified agents around the center, brokers (who trade under their name but at the cost of others) and dealers (who trade under their name and at their own cost). The second circle are agents who do not have the access to the official stock exchange. With every following circle the level of authority on the stock exchange decreases. Stock exchange structure most commonly comprises of three circles, the third of which is the widest market.
Some of jobs that appear in the pattern are: market maker job position- the obligatory trading under their own name and account at the already set price, portfolio manager job position- managing under the name and on the account of the warrant provider, investment advisor job positionproviding counsel service related to exchange market business.

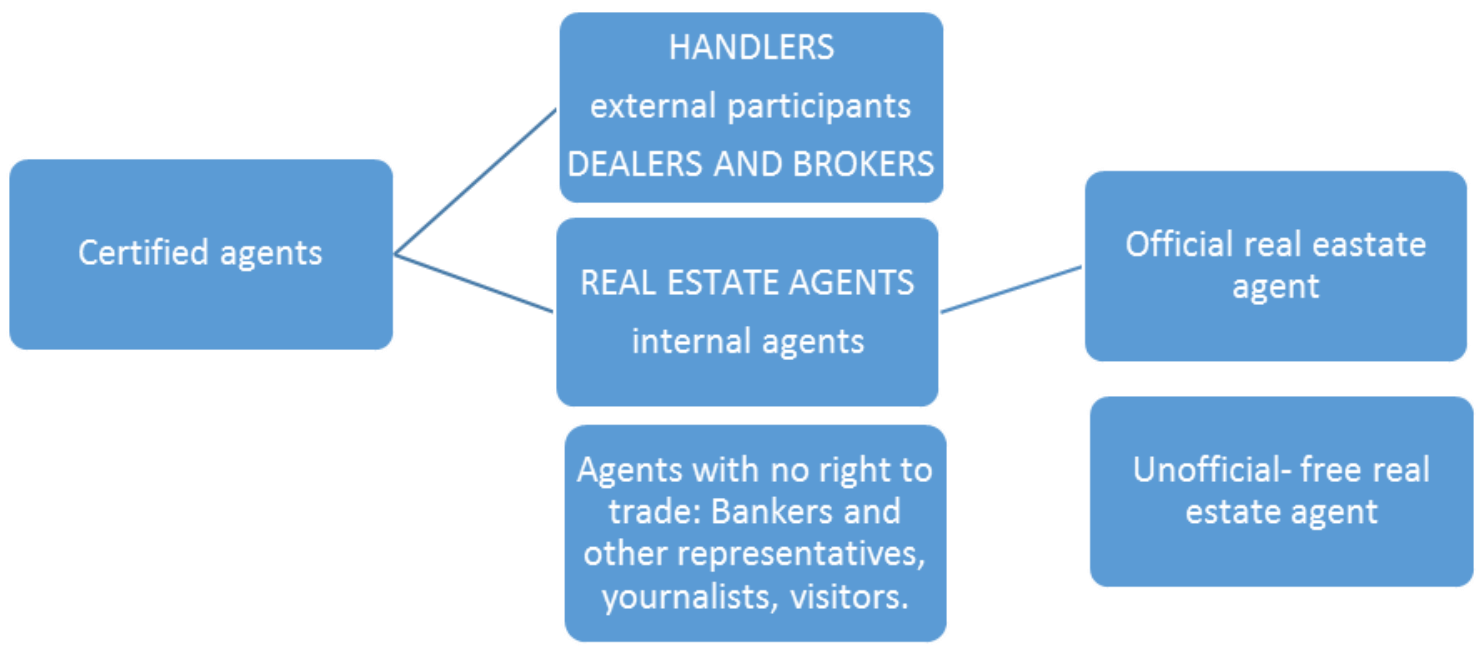

Picture 1. Stock exchange agents

Stock exchanges are organized like stock societies. Stock exchanges are highly organized institutions in developed world markets. They are organized by state as well as by their own regulations. Their operation is mostly depicted in the function of stabilization and equality of market spending.

Some of organizational stock exchange characteristics are:
- Stock exchange is organized as stock exchange and outside of stock exchange organizer

- Stock exchange is organized in the form and shape of a closed stock corporation with no restricted right of vote

- Stock exchange operates as a profit corporation

- Administrative and executive function of stock exchange are separated 
- Administrative stock exchange board has members from stock corporation, which are elected by Parliament, by voting

- Every stock exchange has its own name, assets, number, sort and type of stocks, decision making board, representatives, the time of operation and ending.

Various jobs at the stock exchange can be divided into:

- Official and private, by the case they deal with

- Real and speculative, by the goal

- Prompt and terminal stock exchange jobs, by the time of undertaking arrival.

Prompt jobs are an effective trade of existing goods, either stored or stocked. They are always completed effectively and are not speculative. Unlike them, terminal jobs are permanent insurance from the risk of increase or decrease of the price of goods, or speculation about the variations in price, interest, foreign currency differences. The most important terminal jobs are forwards, futures, options and swap derivatives.

Stock exchange agents are constituent parts of stock exchange operation. Stock exchange agents are legal entities created as stock corporations, registered to trade at the stock exchange. The outside of stock exchanges also have stock corporations. In this case, the shareholder might be a state, a bank, another domestic or foreign, natural or legal entity.

Stock exchange indexes are tools used by stock exchange in order to provide bestquality information to all trading participants and help possible investors make the decision whether or not to invest in them, the most valuable securities.

One of the basic indicators of stability and prosperity of industry in one country is its stock exchange. Stocks have this position owing to their characteristics explained in more detail further in the text.

- Stock exchange market determines the market supply and demand ranking of securities offered.

- Stock exchange price of capital market securities are result of supply and demand relation.

- Co-relation of stock exchange prices is possible in every following meeting. Stock exchange oscillations is a set of all exchange effect movements which are practically reflected in either decrease or increase of the stock exchange instrument currency. Oscillation of securities currency in the capital market which are traded in stock exchange is a consequence of the demand and supply relation for them at the stock exchange. Investors are the ones creating the demand at the stock exchange, because they invest their assets in effects which are rated at the stock exchange. They tend to increase their assets as much as possible. Any new information about the effect issuer has an impact on the co-relation of the investor's already made decision, which further results in effect currency oscillation. Thus, stock exchange is an economic indicator of one nation's industry status and business relation of the investor towards that status. ${ }^{12}$

In order to be able to trade in certain security, it has to be accepted at the exchange matter, and that acceptance is known as listing.

Acceptance conditions are rigorous, for example at the New York stock exchange (NYSE), in order for some financial instruments to be accepted, they need to have:

12 Božić D.; Todorović T.;" Stock exchange business with effects with a special emphasis on trading and Belgrade stock news”, Business school, Scientific magazine 
- At least 2.5 million dollar income prior to taxes in the previous year, or a gross income of 6.5 million dollars for the previous three years;

- Net assets of at least 18 million dollars;

- At least 1.1 million stocks emitted and owned by investors, their gross market value has to be at least 18 million dollars; 82 BUSINESS SCHOOL Scientific magazine.

- At least 2,000 stockers, each of which has to own at least 100 stocks, or 2,200 stockers with an average market span of 100,000 stocks. Looking ahead with the mentioned conditions, it is no wonder that the New York stock exchange is the biggest one in the world. The value of average daily trade was 15.9 billion dollars in 2006. New York stock exchange comprises of more than 2,500 companies whose stocks have around 51 million of individual investors and 2,000 institutional investors at the market. There are around 430 companies ${ }^{13}$ trading on the floor.

\section{CONCLUSION}

Stock exchange business is one of the primary indicators of capital market operation in one country. Stock exchange is an organized institution of capital market. Stock exchange and its business development is the picture of the capital market development in one country. Good capital market operation is a condition for a successful industrial development in one country and an indicator of industrial movements based on which macroanalysts can estimate both short and long-

\footnotetext{
${ }^{13}$ Schwager (2005)
}

term company perspective as well as the overall industrial activities.

Capital global flow in European countries reflects a positive signal, meaning that they are transitioning from the net capital loss to the position of net capital gain, especially in countries such as Poland, Czech Republic, Hungary. When it comes to sectors the most significant capital gains are recorded in financial, construction, and assets sectors.

Drastic changes in the field and structure of financial markets indicate that there is greater instability at the financial market and that we can expect that instability would increase on the basis of the projected trends in informational technology, globalization and financial institutions and a significant growth in market risks.

\section{Literature:}

1. Aničić, J., Simić, N., Petrović, V, Aničić, D., (2017) Financial aspect of current assets management in Sebian economy, Journal Of Process Management - New Technologies International, Volume 5(2), 36-44.

2. Aničić, J., Aničić, D., Majstorović, A., (2017) Accounting and financial reports in the function of corporate governance, Journal Of Process Management - New Technologies International, Volume 5(2), 45- 54.

3. Barać S; Stakić B; Ivanišević M; "Javne finansije" Univerzitet Sigidunum, FFMO, Beograd, 2010.

4. Barjaktarević L; "Monetarno-kreditni I devizni system" Beograd, 2010.

5. Božić D.; Todorović T.;" Berzansko poslovanje efektima sa posebnim osvrtom na trgovanje I aktuelnosti Beogradske berze", Škola biznisa, Naučni časopis

6. Derosa, F. D., (2002) Managing foreign exchange risk: Advanced strategies for global investors, corporation and financial institutions, Irwing, Chicago

7. Dugalić, V., Štimac, Š., (2005) Osnove berzanskog poslovanja, Beograd, Stubovi kulture

8. Engel, L., Boyd, B., (2000) How to buy stocks, New York, Bantam Books 
(JPMNT) Journal of Process Management - New Technologies, International

Vol. 6, No 1, 2018.

9. Kohn, M., (2004) Financial institutions and markets, New York, Oxsford University Press, Inc

10. Krasulja D; Ivanišević M, „Pojam berze i berzansko poslovanje“, Beograd, 1998.

11. Modigiliani, F., Fabozzi, F., (1996) Capital markets, second edition, New Jersey, Prentice Hall International, Inc

12. Ristanović R, „Finansijski menadžment“, Visoka poslovna škola Beograd, skripta, str.13
13. Rutterford, J., (2004) Introduction to stock exchange investment almanac

14. Vasiljević, B., (2006) Finansijska tržišta, peto izdanje, Beograd, Zavet

15. Schwager (2005)

16. http://www.belex.rs/o_berzi/korisni_linko vi

17. http://www.aikb.net/t1269-osnovnipojmovi-berzanske-terminologije 